\title{
Perancangan Infrastruktur Pertanian dalam Konteks Perkotaan
}

\author{
Maria Fransisca Candra Yunita dan Collinthia Erwindi \\ Departemen Arsitektur, Fakultas Teknik Sipil dan Perencanaan, Institut Teknologi Sepuluh Nopember (ITS) \\ e-mail: c_erwindi@arch.its.ac.id
}

\begin{abstract}
Abstrak - Seiring dengan berkembangnya dunia dalam berbagai aspek, muncul beberapa isu dan permasalahan yang kompleks seperti overpopulasi, terorisme, krisis ekonomi global, dan lain sebagainya. Overpopulasi merupakan suatu keadaan dimana jumlah orang dalam suatu kelompok melebihi daya dukung dari wilayah yang ditempatinya. Permasalahan ini sudah mulai terlihat di berbagai kota-kota besar terutama yang terletak di negara berkembang dan menyebabkan tingkat kepadatan penduduk tinggi, kemacetan, polusi, dan lain-lain. Salah satu dampak terbesar dari overpopulasi adalah kaitannya dengan ketersediaan bahan pangan. Area pertanian di kota semakin berkurang, sedangkan jumlah penduduk dan permintaan bahan pangan mulai meningkat. Hal tersebut dapat mengakibatkan kenaikan harga bahan pokok karena terbatasnya atau kurangnya ketersediaan bahan pangan yang ada sehingga terpaksa mengimpor dari daerah lain. Oleh karena itu dibutuhkan inovasi terutama pada bidang pertanian skala kota untuk mengatasi permasalahan ini. Berdasarkan isu tersebut, muncul inovasi obyek arsitektural "Taman Pertanian Kota" yang berfungsi sebagai sarana infrastruktur penyedia bahan makanan sekaligus pendidikan teknologi pertanian. Metode yang digunakan dalam proses perancangan obyek ini adalah kontekstualisme dengan pendekatan secara ekologis.
\end{abstract}

Kata Kunci-Ekologis, Kontekstualisme, Overpopulasi, Pertanian Kota.

\section{PENDAHULUAN}

$\mathrm{O}$ VERPOPULASI merupakan suatu keadaan dimana jumlah orang dalam suatu kelompok melebihi daya dukung dari wilayah yang ditempatinya [1]. Permasalahan ini sudah mulai terlihat di berbagai kota-kota besar terutama yang terletak di negara berkembang. Dr. Dickson Despomier dalam bukunya Feeding the World in $21^{\text {st }}$ Century mennyatakan:

1. Pada Tahun 2050 kurang lebih $80 \%$ populasi manusia hidup di perkotaan

2. Dalam waktu dekat ini pertumbuhan populasi manusia dapat mencapai 3 miliar

3. Dibutuhkan lahan pertanian seluas $10^{9}$ hektar lahan pertanian untuk mencukupi kebutuhan pangan manusia di dunia [2].

Kota Surabaya yang merupakan kota terpadat kedua di Indonesia, memiliki potensi terjadinya overpopulasi yang akan berdampak pada ketersediaan bahan pangan. Pada tahun 2010 kota Surabaya memiliki jumlah penduduk 2.806.306 jiwa

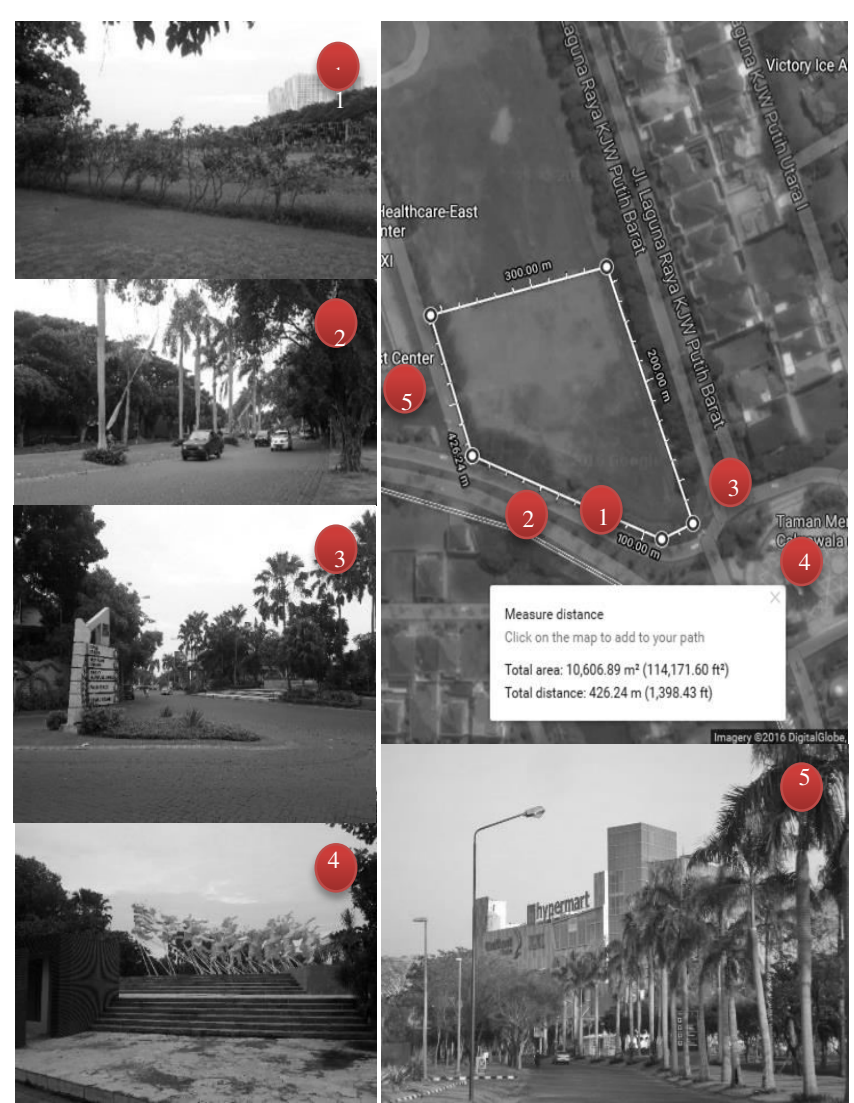

Gambar 1. Lokasi Tapak dan Lingkungan Sekitar

Sumber: Dokumentasi Pribadi dan Google

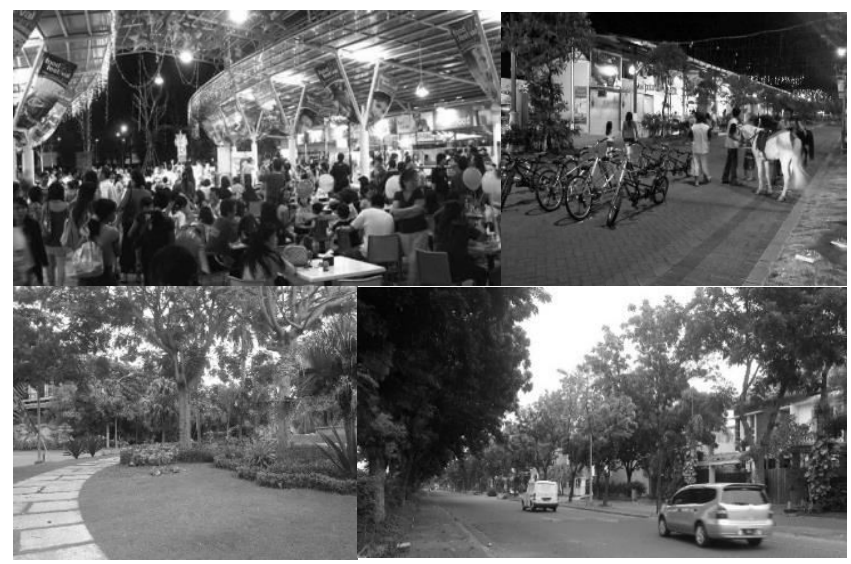

Gambar 2. Aktivitas Lingkungan Sekitar

Sumber: Dokumentasi Pribadi dan Google 
dengan luas wilayah $350.54 \mathrm{~km}^{2}$. Luas lahan pertanian kota Surabaya saat ini mencapai 1.400 hektar, berkurang 300 hektar dari tahun 2015 [3].

Respon arsitektural berdasarkan permasalahan dan isu diatas adalah "Taman Pertanian Kota". Taman Pertanian Kota adalah infrastruktur pertanian dan pendidikan teknologi pertanian dengan sistem pertanian modern (mengunakan greenhouse dengan sistem hidroponik dan vertikultur) yang dapat memproduksi bahan pokok dalam waktu lebih cepat dengan jumlah yang besar. Lokasi dari obyek ini terletak di Jalan Laguna Raya Kejawan Putih Barat, Surabaya bagian timur (Gambar 1). Lokasi ini dipilih karena berdekatan dengan fasilitas-fasilitas umum dan pemukiman penduduk. Tujuan dari Obyek ini adalah sebagai pusat produksi pertanian organik, pendidikan pertanian, dan area belanja bahan pokok pangan. Dengan adanya obyek ini, dapat menambah kualitas kesegaran hasil panen karena tidak lagi didistribusikan dari luar daerah dan jumlah panen meningkat dalam waktu lebih cepat.

\section{METODA PERANCANGAN}

Pendekatan perancangan yang digunakan dalam obyek arsitektural ini adalah kontekstual dengan prinsip arsitektur ekologis. Terdapat dua kelompok dalam arsitektur kontekstual yaitu kontras dan harmoni. Kontekstualisme yang bersifat kontras artinya obyek arsitektural memiliki karakter yang berbeda dengan bangunan disekitarnya namun tetap memiliki sedikit harmoni dengan apa yang ada disekitarnya. Sedangkan konteksualisme yang bersifat harmoni, obyek arsitektural memiliki karakter / bentuk / langgam yang selaras dengan yang sudah ada pada lingkungan sekitarnya [4]. Berdasarkan buku Eco Tropical House (Imelda Akmal) terdapat empat prinsip arsitektur ekologis yaitu:

1. Pemilihan material

2. Efisiensi Energi

3. Masa huni bangunan dan fleksibilitas

4. Kontekstualitas desain terhadap tapak (Garis tapak, garis kontur) [5].

Pendekatan kontekstual yang dipilih dalam proses perancangan obyek arsitektural ini adalah metode kontekstual yang bersifat kontras karena fungsi infrastruktur pertanian identik dengan area rural atau suburban sedangkan lokasi obyek terletak di perkotaan. Sedangkan untuk prinsip arsitektur ekologis lebih di maksimalkan pada poin pemilihan material, efisiensi energi, dan kontekstualisme terhadap tapak.

\section{HASIL DAN EKSPLORASI}

Kriteria rancang pada obyek arsitektural ini adalah:

1. Bangunan memiliki area produksi pertanian yang dapat dibuka untuk publik dalam rangka pengalaman dan pembelajaran, dan memiliki area produksi utama yang bersifat steril atau privat
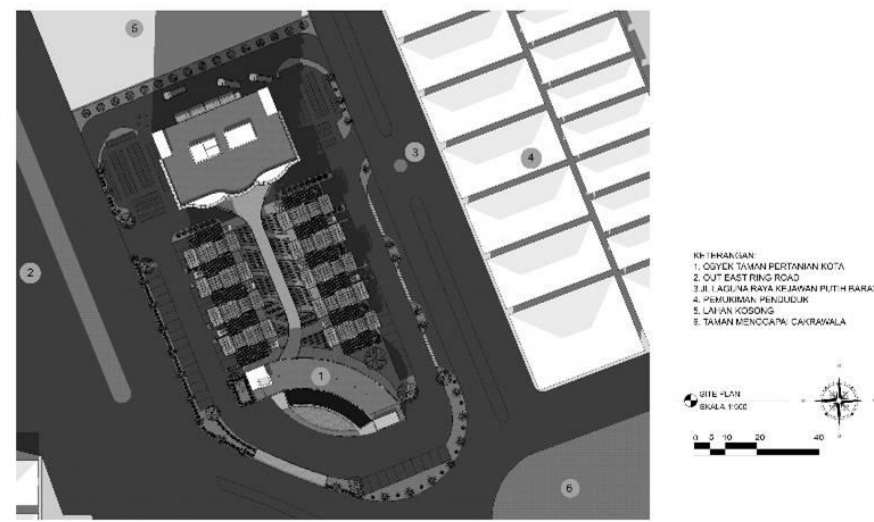

Gambar 3. Site Plan Obyek Arsitektural

Sumber: Dokumentasi Pribadi

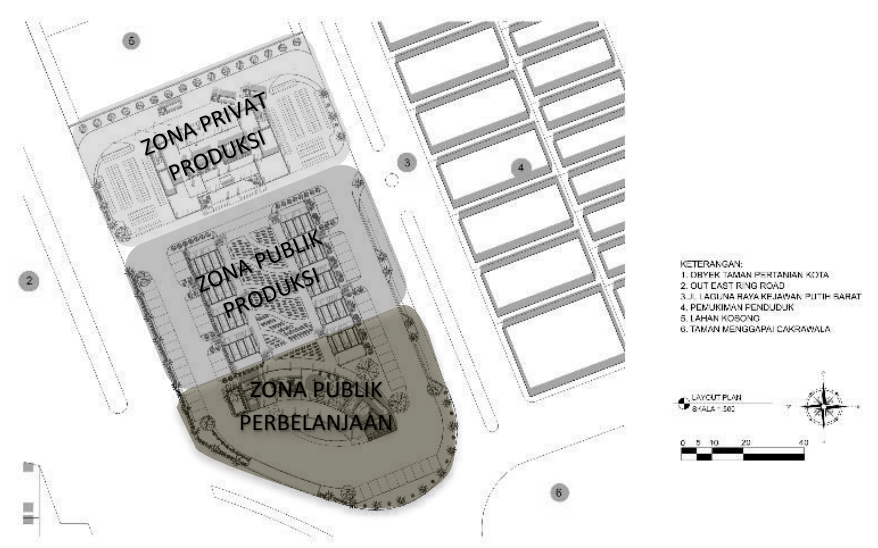

Gambar 4. Layout Plan Obyek Arsitektural

Sumber: Dokumentasi Pribadi
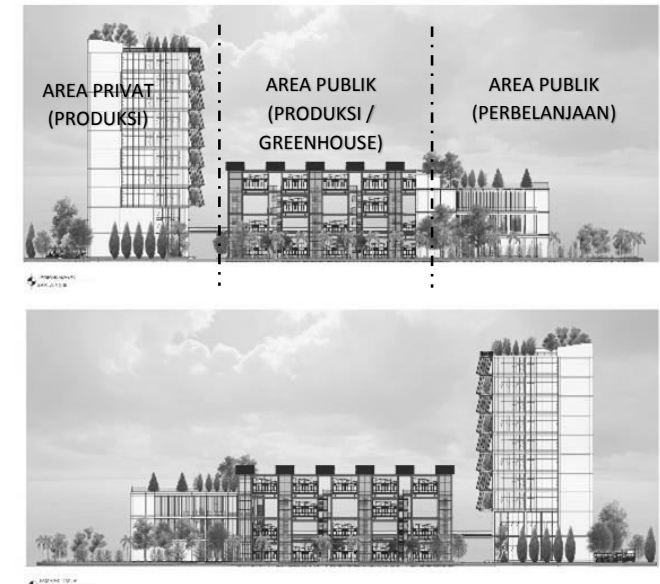

s.m.....

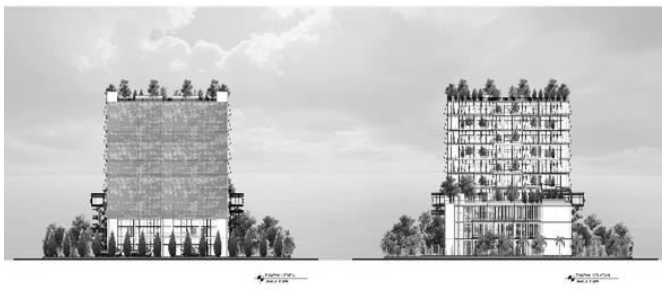

Gambar 5. Tampak Obyek Arsitektural dan Zoning

Sumber: Dokumentasi Pribadi 
2. Bangunan dapat memaksimalkan pencahayaan alami untuk proses pertanian dan efisiensi energi

3. Memiliki alternatif sumber energi alami (panel surya) untuk efisiensi dan cadangan energi

4. Bangunan menggunakan pengkondisian udara buatan untuk mengoptimalkan pertumbuhan tanaman pertanian

5. Pemilihan tanaman didasarkan pada sistem penanaman yang digunakan pada masing-masing ruang pertanian (Greenhouse menggunakan sistem hidroponik NFT, area pertanian gedung produksi utama menggunakan vertikultur dan hidroponik NFT, dan area outdoor menggunakan sistem pertanian konvensional)

Berdasarkan beberapa kriteria yang telah ditentukan untuk obyek arsitektural terdapat tiga zonasi. Area selatan tapak digunakan sebagai area perbelanjaan publik karena area tersebut dekat dengan bundaran utama terbesar di area kompleks dan memiliki mobilitas kendaraan yang cukup tinggi. Area paling utara digunakan sebagai pusat produksi utama karena mobilitas kendaraan dan manusia yang sedang, sehingga dapat meminimalkan keinginan dan akses mayarakat umum untuk masuk ke area tersebut. Sedangkan area pada bagian tengah tapak digunakan sebagai area produksi pertanian publik yang tersusun dari beberapa greenhouse yang disusun secara vertikal yang juga untuk memberikan masyarakat pengalaman bertani modern.

Berikut adalah beberapa konsep bentuk dan penerapannya serta pemakaian material bedasarkan kriteria-kriteria diatas:

1. Area produksi pertanian yang terbuka untuk publik menggunakan sistem Vertical Sliding Greenhouses, dimana bangunan greenhouse disusun secara vertikal dan dapat bergerak menyesuaikan dengan kondisi lingkungan (pencahayaan) disesuaikan dengan kebutuhan tanaman didalamnya. Rangka untuk penempatan greenhouse menggunakan material baja dan memiliki rel pada tempat perletakan greenhouse untuk proses pergerakan greenhouse saat menyesuaikan dengan arah datang cahaya. (Gambar 7)

2. Area produksi pertanian utama dengan konsep vertikal Full Transparent Façade yaitu fasad transparan dengan bentuk bergelombang dan memiliki dua bentuk berbeda beraturan yang disusun secara bergantian pada bagian depan (selatan) untuk memaksimalkan pencahayaan pada tiap lantai dan pada bagian belakang (utara) fasad menggunakan greenpix photovoltaic led façade sebagai alternatif energi (tidak sepenuhnya menggunakan energi dari PLN). Rangka jendela pada fasad menggunakan rangka UPVC dengan kaca uv double setebal $20 \mathrm{~mm}$. UPVC dipilih karena merupakan material yang kuat dan tahan lama dengan pemeliharaan yang mudah atau minimal. (Gambar 8)

3. Area komersial sedikit mengadopsi dari bentuk lengkung area produksi dengan sebagian besar fasad bersifat transparan (curtain wall) dengan rangka

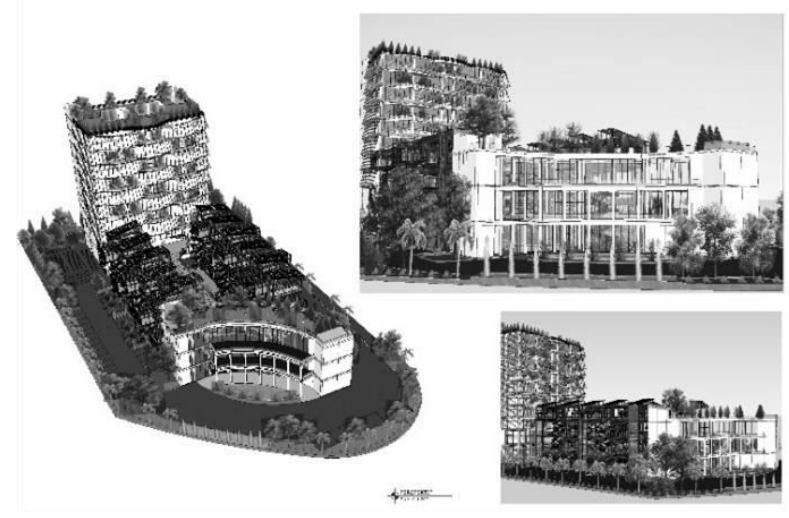

Gambar 6. Perspektif Obyek Arsitektural

Sumber : Dokumentasi Pribadi

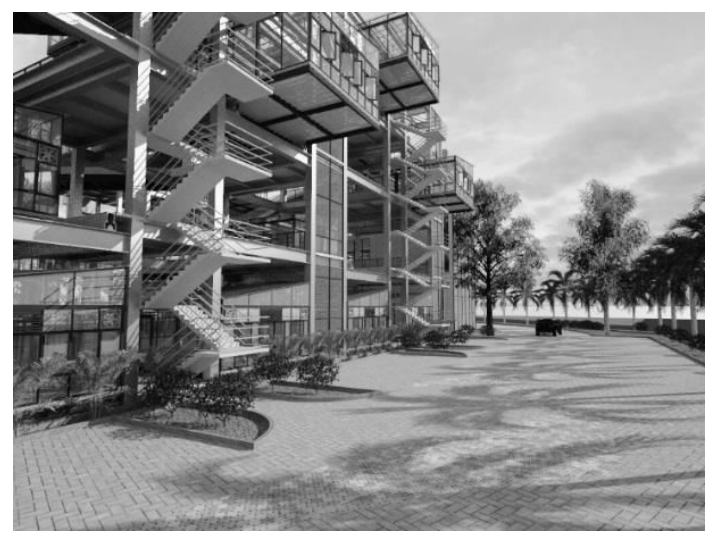

Gambar 7. Area Greenhouse

Sumber : Dokumentasi Pribadi

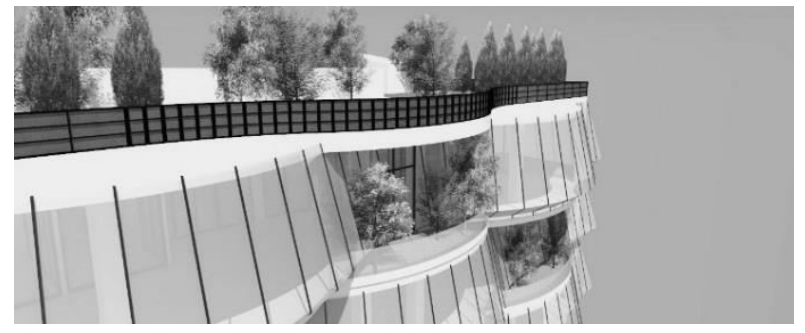

Gambar 8 . Detail Fasad Gedung Produksi

Sumber : Dokumentasi Pribadi

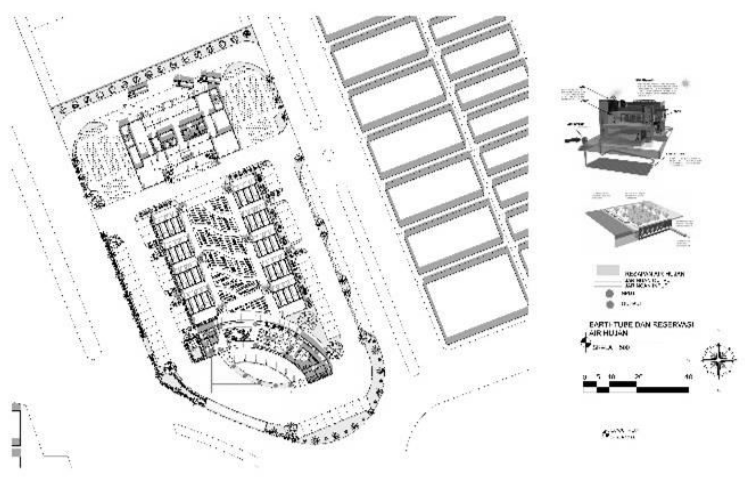

Gambar 9. Perletakan Earthtube

Sumber : Dokumentasi Pribadi 
4. curtainwall terbuat dari UPVC dan memiliki kolam air (fountain) sebagai vocal point sebagai penanda bahwa area tersebut merupakan area kedatangan dan komersial. (Gambar 7)

5. Untuk pengkondisian udara menggunakan sistem earthtube (pendinginan dengan geothermal). (Gambar 9)

6. Ruang terbuka diantara bangunan greenhouse digunakan sebagai taman pertanian dengan sistem konvensional yang dibuka untuk publik sebagai sarana rekreasi dan pembelajaran dasar tentang pertanian.

7. Garis bangunan komersial hingga produksi (dapat dilihat pada site plan Gambar 1) mengikuti garis tapak untuk memaksimalkan penggunaan tapak dan menyesuaikan dengan bangunan-bangunan di sekitarnya yang hampir secara keseluruhan mengikuti bentuk garis tapak masing-masing.

8. Konsep utilitas pada greenhouse adalah Flexible Utility dimana saluran utilitas (air dan kabel listrik) dimasukan kedalam pipa fleksibel berbahan metal dengan cara kerja seperti pada kabel penghubung antara mesin dan pointer laser pada alat laser cutting. Hal itu untuk memudahkan distribusi utilitas pada greenhouse yang bergerak pada saat tertentu. (Gambar 10 dan 11)

\section{KESIMPULAN}

Dalam proses perancangan obyek arsitektural "Taman Pertanian Kota" ini menggunakan metode kontekstual untuk mewujudkan infrastruktur pertanian yang memiliki karakteristik khusus dalam skala perkotaan. Obyek terbagi menjadi tiga area yaitu area komersial, area produksi (terbuka untuk komersial), dan area produksi utama (privat). Penerapan kontekstualisme pertanian terlihat dari penggunaan greenhouse dan banyaknya fasad transparan untuk memaksimalkan pencahayaan alami pada tiap ruang produksi sehingga menimbulkan kesan kontras dengan lingkungan yang ada disekitarnya. Untuk kontekstualisme perkotaan diterapkan lebih kepada bentuk bangunan produksi berlantai banyak dan beberapa material fasad yang sama dengan bangunan di sekitar yaitu ACP (Aluminium Composite Panel) dan curtain wall. Sedangkan untuk pemenuhan prinsip ekologis diterpakan pada pemakaian fasad transparan untuk memaksimalkan cahaya, greenhouse yang dapat bergerak menyesuaikan arah datang cahaya, fasad greenpix dan solar panel sebagai sumber energi alternative (Gambar 12), dan penggunaan earthtube yaitu alat penkondisian udara aktif yang menggunakan sistem pendinginan udara secara geotermal. Obyek ini memiliki tujuan utama sebagai solusi untuk mencegah kekurangan bahan pangan, penurunan kualitas bahan pangan (akibat jangka waktu distribusi) dan sebagai pusat penghasil bahan pangan organik kota Surabaya. Selain itu obyek ini juga dapat digunakan sebagai tempat pembelajaran teknologi pertanian untuk masyarakat dan akademisi.

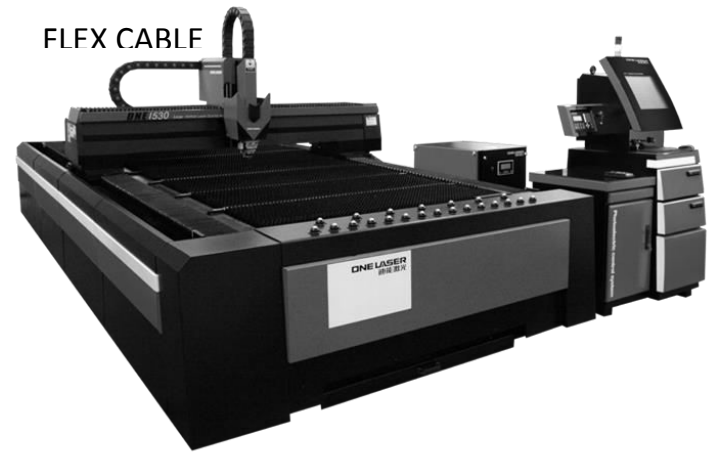

Gambar 10 . Flex Cable pada mesin laser cut Sumber : Dokumentasi Pribadi

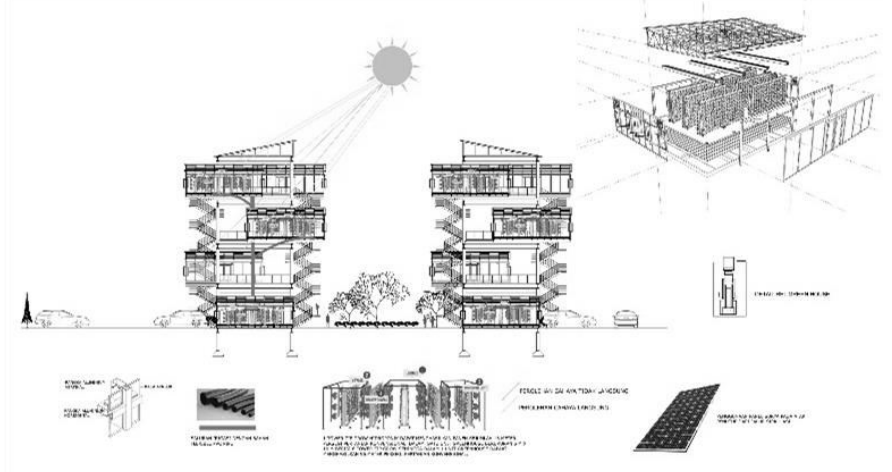

Gambar 11 . Potongan dan Detail Greenhouse Sumber : Dokumentasi Pribadi

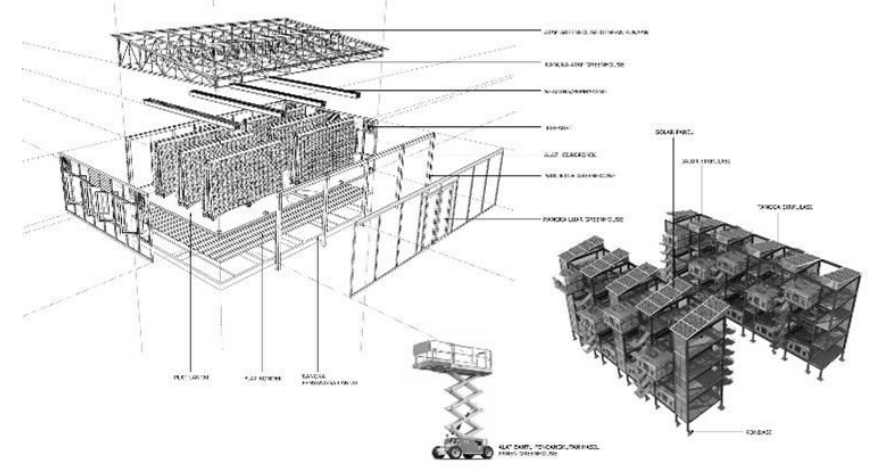

Gambar 12 . Detail Greenhouse

Sumber : Dokumen Pribadi

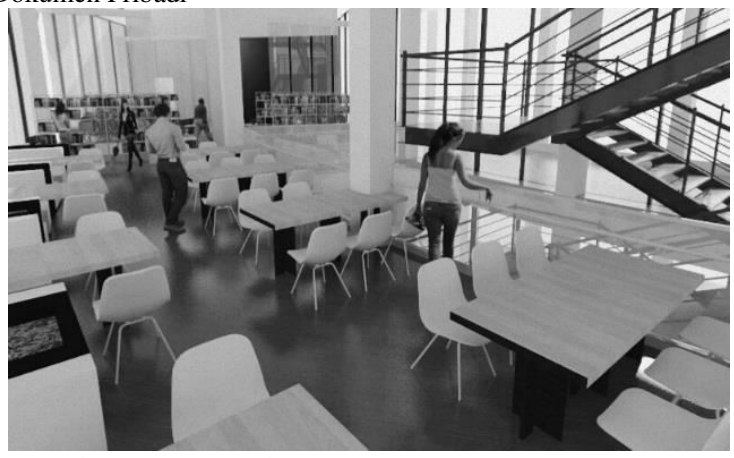

Gambar 13 . Interior Area Komersial

Sumber : Dokumen Pribadi 


\section{DAFTAR PUSTAKA}

[1] Wikipedia, "Human Overpopulation," 2016. [Online]. Available: https://en.wikipedia.org/wiki/Human_overpopulation.

[2] D. Despommier, The Vertical Farming: Feeding the Wolrld in the 21st Century. New York: St. Martn's Press, 2011.

[3] ilmupengetahuanumum.com, "10 Kota Tebesar di Indonesia Menurut Jumlah Penduduknya," 2016. [Online]. Available: http://ilmupengetahuanumum.com/10-kota-terbesar-di-indonesiamenurut-jumlah-penduduknya/, .

[4] R. Nurdin, "Studi Literatur Mengenai Arsitektur Kontekstual," 2012. [Online]. Available:

https://arsitekturbicara.wordpress.com/2012/05/19/studi-literaturmengenai-arsitektur-kontekstual/.

[5] I. Akmal, House Series: Tropical Eco house. Jakarta: Imaji, 2015. 